\title{
A COMPARATIVE ANALYSIS OF THE EXPRESSIONS OF GIVING AND RECEIVING IN THE TATAR AND JAPANESE LANGUAGES
}

\author{
UMA ANÁLISE COMPARATIVA DAS EXPRESSÕES DE DAR E RECEBER NAS \\ LÍNGUAS TARTARA E JAPONESA
}

\author{
UN ANALISIS COMPARATIVO DE LAS EXPRESIONES DE DAR Y RECIBIR EN LOS \\ IDIOMAS TÁRTARO Y JAPONÉS
}

\author{
Venera Nafikovna KHISAMOVA ${ }^{1}$ \\ Alina Airatovna KHALIULLINA ${ }^{2}$ \\ Rafik Rashitovich MAGDEEV ${ }^{3}$
}

\begin{abstract}
Comparing two languages may lead to results that would help to deeper understand both languages under analysis and may be helpful to see the language from a new side. The results which are achieved by the comparative method, showing common features of the languages being compared, make the process of studying a foreign language easier. As the Tatar speaking audience does not commonly study Japanese language, studying it through the mother language can make the process of studying and acquisition less difficult. Being the representatives of agglutinative languages, the Tatar and the Japanese have common features that have to be studied by the comparative linguistics. This article deals with the constructions, which consist of verbal adverb and modal verb in Tatar and Japanese languages whose meaning is to give/to receive. Such constructions are analyzed and compared in terms of their grammatical form, semantics and considered through the lens of cultural linguistics.
\end{abstract}

KEYWORDS: Comparative linguistics. Tatar language. Japanese language. Phrases of giving and receiving. Jujuhyougen.

RESUMO: A comparação de dois idiomas pode levar a resultados que ajudariam a entender mais profundamente os dois idiomas analisados, podendo ser útil ver o idioma de um novo ângulo. Os resultados alcançados pelo método comparativo, mostrando características comuns das línguas comparadas, facilitam o processo de estudo de uma língua estrangeira. Como o público que fala tártaro geralmente não estuda a língua japonesa, estudá-la na língua materna pode tornar o processo de estudo e aquisição menos difícil. Por serem representantes de línguas aglutinativas, os tártaros e os japoneses têm características comuns que devem ser estudadas pela linguística comparada. Este artigo trata das construções, que consistem em advérbio verbal e verbo modal nas línguas tártara e japonesa cujo significado é dar / receber. Tais construções são analisadas e comparadas em termos de sua forma gramatical, semântica e consideradas pelas lentes da linguística cultural.

1 Kazan Federal University (KPFU), Kazan - Russia. Institute of International Relations. ORCID: https://orcid.org/0000-0001-7544-8473. E-mail: venerakhisamova2019@gmail.ru

2 Kazan Federal University (KPFU), Kazan - Russia. Institute of International Relations. ORCID: https://orcid.org/0000-0003-1018-0634.E-mail: alina.khaliullina27@gmail.com

3 Kazan Federal University (KPFU), Kazan - Russia. Institute of International Relations. ORCID: https://orcid.org/0000-0002-2216-0051. E-mail: magdeevrr2020@gmail.com 
PALAVRAS-CHAVE: Linguística comparada. Língua tártara. Língua japonesa. Frases de dar e receber. Jujuhyougen.

RESUMEN: La comparación de dos idiomas puede llevar a los resultados, lo que ayudaría a comprender mejor ambos idiomas bajo el análisis, y puede ser útil ver el idioma desde un nuevo lado. Los resultados que se obtienen mediante el método comparativo, que muestran características comunes de las lenguas comparadas, facilitan el proceso de estudio de una lengua extranjera. Como la audiencia de habla tártara no suele estudiar el idioma japonés, estudiarlo a través de la lengua materna puede hacer que el proceso de estudio y adquisición sea menos difícil. Al ser representantes de lenguas aglutinantes, el tártaro y el japonés tienen rasgos comunes que deben ser estudiados por la lingüística comparada. Este artículo trata de las construcciones, que consisten en adverbio verbal y verbo modal en lenguas tártaras y japonesas cuyo significado es dar / recibir. Estas construcciones se analizan y comparan en términos de su forma gramatical, semántica y se consideran a través de la lente de la lingüistica cultural.

$\boldsymbol{P A L A B R A S ~ C L A V E : ~ L i n g u ̈ i s t i c a ~ c o m p a r a d a . ~ L e n g u a ~ t a ́ r t a r a . ~ L e n g u a ~ j a p o n e s a . ~ F r a s e s ~ d e ~}$ dar y recibir. Jujuhyougen.

\section{Introduction}

The aim of this research is to study the ways of transferring benefactive meanings in Tatar and Japanese languages and to identify typological correspondences in terms of semantics and grammatical expression of phrases of giving and receiving. Also, these phrases are considered in the aspect of cultural linguistics in order to identify cases of using structures with benefactive meaning depending on the relationships of the object and the subject in the hierarchy. According to Glushkova and other researchers, the analysis of two languages from the cultural point of view, can contribute to knowledge of culture (GLUSHKOVA; TKHOMPIRA; SILAKOVA, 2019; IBATULLINA; ALIKBEROVA; NASIROVA 2019). In other words, the more common features of two cultures are identified, the more effective international communication is held.

In Japanese language, there are special constructions that are used to indicate actions performed for someone's benefit. According to Alpatov, Arkadyev and Podlesskaya (2008), such constructions are called "benefactive". Benefactive constructions in Japanese are formed with the adverbial -te form and one of the auxiliary verbs, which mean "to give" or "to receive".

The grammaticalized use of verbs that mean "to give"/"to receive" in the Japanese is determined by the semantic peculiarities of verbs with the meaning "to give"/"to receive" in independent usage. It should be mentioned that in the Japanese the verbs "to give" and "to receive" are expressed in a number of lexical items depending on the situation of usage. Thus, 
for example, the verb "to give" in Japanese can sound like ageru, kureru, sashiageru etc. The verb "receive" also has several ways of expression: morau, itadaku. The usage of a verb depends on the following factors: from whose point of view the situation is described - whether it is described from the point of view of the one who gives or the one who receives; how the speaker estimates the position of the subject in the social hierarchy.

In the Tatar there are also the verbs which mean "to give" and "to receive": alyrga, birerge (алырга, бирергә) (ZAKIEV, 1993).

Next, we are going to show the examples of usage of verbs of giving and receiving in Tatar language and the analysis of the ways of their expression in Japanese language. The grammatical constructions with the verbs of giving and receiving will be analyzed not only from its' morphological point, but also from the point of view of culture and politeness of both languages.

\section{Methods}

For making the analysis, we used the method of comparison and the method of survey. We took the examples of using the benefactive constructions from the classic Tatar literature and by the method of translation them into Japanese language, we discovered the ways of expressing these grammatical constructions in Japanese language. We have found not only common grammatical structure of two languages, but also the common features from the cultural point of view. We also hold the survey for analysis of usage of the benefactive constructions in modern Tatar language. Further, we are going to discuss the results of both methods.

\section{Results}

Let us consider some examples of the usage of these verbs in the sentence:

Мин аңа китап бирдем. (I gave a book to him).

私は彼に本をあげた。Watashi-wa kare-ni hon-o ageta.

Ул миңа китап бирде. (He gave me a book.).

彼が私に本をくれた。Kare-ga watashi-ni hon-o kureta.

Мин аннан китап алдым. (I recieved a book from him).

私は彼に本をもらった。Watashi-wa kare-ni hon-o moratta. 
The verb birerge (бирергə) of Tatar language corresponds in Japanese to the verbs ageru and kureru, depending on whether the object is giving or receiving. The verb alyrga (альрга) of Tatar language corresponds to the verb morau of the Japanese language.

It is well-known fact that Japanese society is hierarchical, and due to the fact that culture makes impact on the language, this fact could not help being reflected in the language. The verb with the meaning "to give" in Japanese has the following usages: if the speaker gives something to someone he does not consider to take higher social position, the verb ageru is used; the verb sashiageru is used in the situation when the speaker gives something to someone whose social status he estimates higher than his own one; if the addressee of the action is the speaker, and the one who gives something to the speaker is not considered by the speaker to be hierarchically higher, the verb kureru is used; and, consequently, if the one whom the speaker estimates as higher in the hierarchy than himself gives something to the speaker, the verb kudasaru is used. A verb with the meaning "to receive" can be translated as morau, if the speaker gets something from someone, whom he does not consider to be higher in the hierarchy, and itadaku, if the speaker gets something from someone he considers to take higher position than himself in the hierarchy.

In Tatar language, the category of benefactive grammatical structures with an auxiliary verb is not indicated as a separate one. However, after analyzing a number of examples from fiction, we came to the conclusion that constructions with benefactive meaning also exist in Tatar language. The grammatical form of the construction in Tatar language is completely identical to the constructions with benefactive meaning in Japanese. In the Tatar language, such a form consists of the adverbial form with the addition of a modificatory verb with the meaning "to give".

Let's consider some examples of the usage of benefactive constructions with the verb birerge (бирергә)in Tatar language:

1) Вәлиәхмәт, салып бир инде бераз гына. (T. Minnullin) "Vakiakhmet, pour him a little".

ヴァリアフメットさん、彼に少し入れてあげて。Wariahumetto-san, kare-ni, sukoshi irete-agete. (Author's translation)

2) Матур икән. Миңа да язып бирерсең. (Т. Minnullin) “It's very beautiful. Write for me too". 
とてもきれいです。私にも書いてくれ。Totemo kirei-desu. Watashi-ni-mo kaitekure. (Author's translation)

3) Шуннан алар калын тавышлы берәүнең килгәнен сөйләп бирәләр. (Tatar national fairytale) "After that, they told that someone with deep voice had come".

それから、彼らは声が低い人の来たことを話してあげる。Sore-kara，karera-wa koe-ga hikui hito-no kita koto-o hanashite-ageru. (Author's translation)

4) Шуның өчен Аю Хатынга бер умарта бал китереп биргән, ди. (Tatar national fairytale) "In gratitude the Bear brought the Woman the hive full of honey".

それでくまが彼女にはちみつをいっぱい持ってきてあげたそうです。 Sore-de kuma-ga kanojyo-ni hachimitsu-o ippai mottekite-ageta-so:-desu. (Author's translation)

5) Кыз аңа икмәген бүлеп биргән. Куян икмәк сыныгын тәмләп кенә ашап куйган да: «Яхшылыкка - яхшылык», - дип, аңа куян бүреге китереп биргән. (Tatar national fairytale) The girl shared bread with him (with the hare). The hare, having eaten bread with good appetite, said, "Kindness is always responded by kindness", and brought a hare hat to the girl.

彼女はウサギに自分のパンを分けてあげました。ウサギはパンを食べてしま って、「優しさに優しさで答える」と言って、ウサギの帽子を持ってきてあげまし

た。Kanojyo-wa usage-ni jibun-no pan-o wakete-agemashita. Usagi-wa pan-o tabete-shimatte, $\lceil$ yasashisa-ni yasashisa-de kotaeru」-to itte, usagi-no bo:shi-o mottekite-agemashita. (Author's translation)

6) Яле, доктор, син - укыган кеше, аңлатып бир әле. (T. Minnullin) “Doctor, you are a well-educated person, please, explain me".

先生、あなたはたくさん勉強した人です、説明してくれ。 Sensei， anata-wa takusan benkyoshita hito-desu, setumei shite-kure. (Author's translation)

7) Берәр кыз да табып бирербез. (T. Minnullin) “We will find (him) even a girl”. 彼女も探してあげるよ。Kanojyo-mo sagashite-ageru-yo. (Author’s translation)

In the examples, given above, when translating from Tatar into Japanese, we used the benefactive constructions with verbs -ageru and -kureru. The verb-kureru was used when the speaker was the addressee of the action. Considering the context, in our opinion, examples 2) and 6) indicate friendly relations between interlocutors, that's why we used the verb -kureru, and not the verb -kudasaru.

In Japanese language there is a special rule that regulate the usage of verbs with meaning "to give" / "to receive". At the same time, in our opinion, Tatar speaking people use or do not 
use the construction with benefactive meaning relying on intuition. According to the fact, that in Tatar language we consider the construction with the auxiliary verb which means "to give" to be the benefactive one, we conducted a survey among the people who speak Tatar. The survey was conducted in order to elicit the usage of the benefactive form -yp biru ( ви биру) when the speaker addressed to someone whom he considered to be 1) not higher in the hierarchy (to a friend), 2) higher in the hierarchy (to teachers). The respondents were given two phrases for translation from the Russian into the Tatar that described two different situations: 1) conversation with a friend; 2) presentation in front of teachers.

1) It seems you don't know how to read this hieroglyph. I will read it for you (Let me read it for you).

2) Now I will read the extract from the composition for you. (Now I am going to read the extract from the composition for you).

The survey involved 45 people whose mother tongue is Tatar or who study it.

Figure 1 - The usage of the form -yp biru (-bln биру) in the situation 1

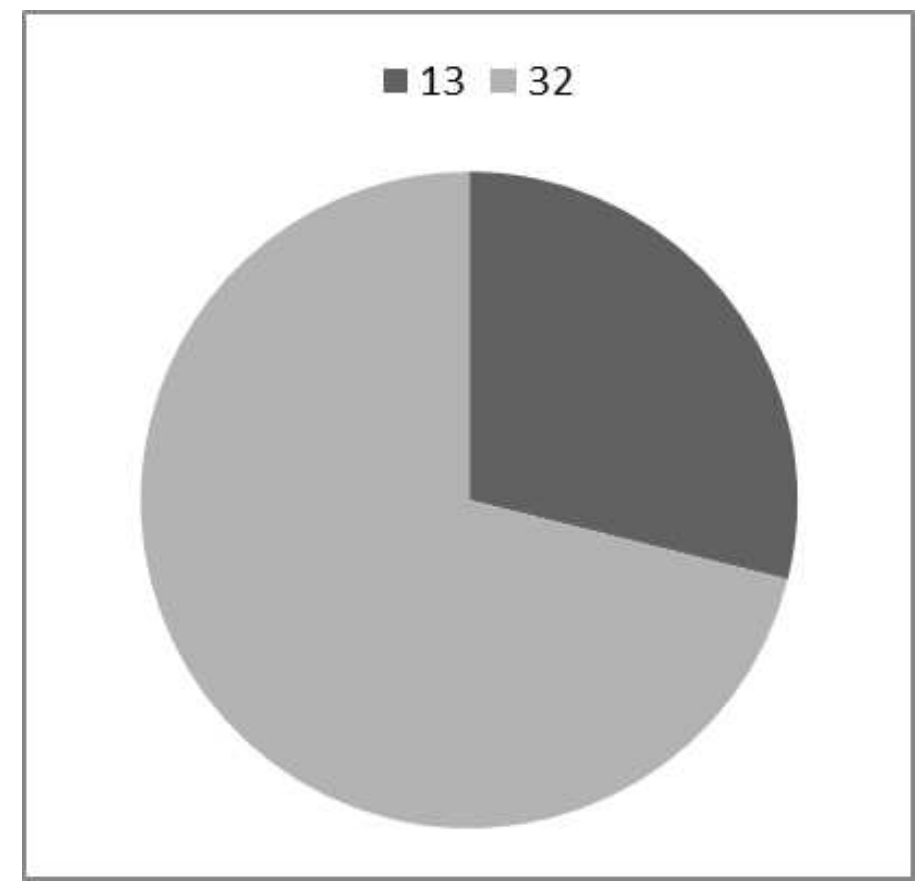

Notes: * The amount of respondents: 45 persons ** The amount of people who when translating used the construction -yp biru (-ып биру): 32 persons

Source: Prepared by the authors 
Figure 2 - The usage of the form -yp biru (-bin биру) in the situation 2

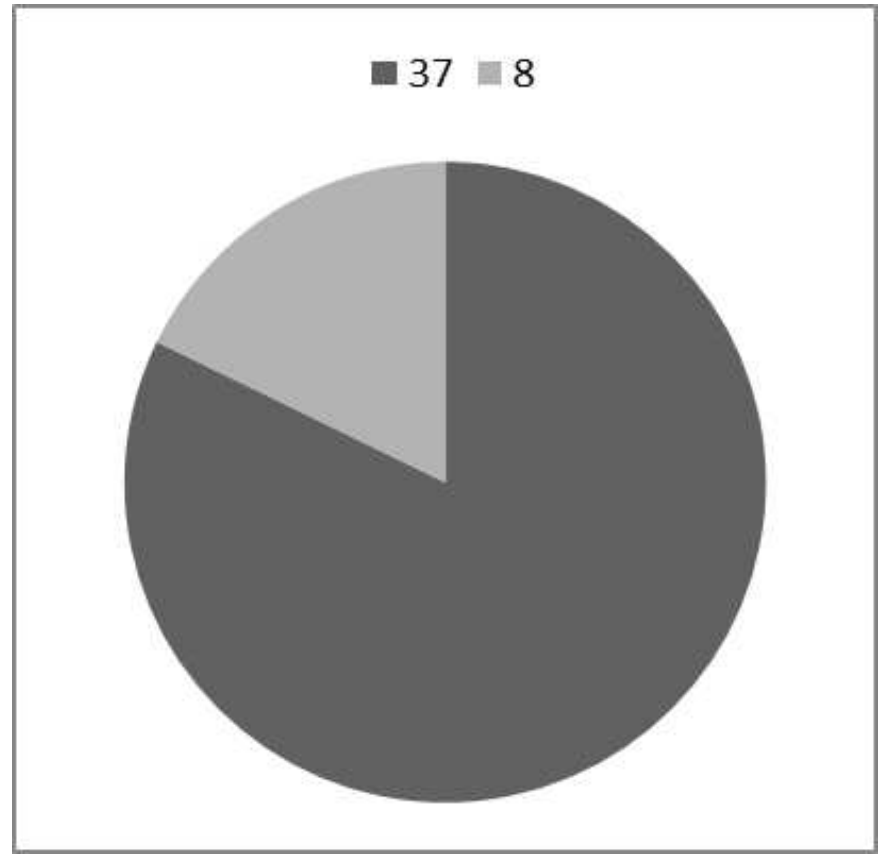

Notes: * The amount of respondents: 45 persons ** The amount of people who when translating used the construction -yp biru (-bin бupY): 8 persons

Source: Prepared by the authors

As we can see from the survey results, the translation of the verb "will read" varies depending on the situation. The form -yp biru (-bin биру) is more common when the addressee is not considered by the speaker as a higher person in the hierarchy. Thus, we can conclude that the use of the benefactive structure with the verb bir (бир) in Tatar language really depends on a communicative situation.

We should underscore that the form that includes a modificatory verb with the meaning "to receive" also exists in Tatar language, however, its meaning does not fully coincide with the meaning of the same form in Japanese. Let us consider the construction of the verb-alyrga (-альрга) which means 'to receive' or 'to take' in Tatar language. According to the verb form, this construction is identical to the verb -birerge (-бирергə) that means 'to give': to the main verb in the adverbial form, ending in -yp (-bln) we add the modificatory verb-alyrga (-альрга) with the meaning 'to receive' or 'to take'. According to Zakiev (1993), this form expresses:

1.performing an action in a very short time: Чү! Газраил канатларын селкеп алды. (H. Taktash) Gazrail shook up wings. ガズライールが羽を震わせた。Gazurai:ru-ga haneo furuwaseta. (Author's translation)

2.action which occurs in a relatively short period of time: Без бергәләп киттек. Бергә борчак жыйдык. Шаяра-шаяра сөйләнеп, талашкалап алдык. (G.Ibragimov) We went out 
together. We gathered peas together. Then, while joking, we quarreled. 私たちは一緒に出掛 けました。一緒に枝豆狩りをしました。楽しんでしやべったり、倠訽味に暴言を 吐いたりしました。 (Перевод автора) Watashitachi-wa isshyo-ni dekakemashita. Isshyo-ni edamame kari-o shimashita. Tanoshinde shyabettari, jyo:dangimi-ni bo:gen-o haitari shimashita. (Author's translation)

3.completion, result of an action: Бар биргәнең тартып алдың да кимсеттең. (Н. Taktash) You robbed of everything I gave you, and humiliated me. あなたは私にくれた物を すべて私から奪い、私を侮辱した。Anata-wa watashi-ni kureta mono-o subete watashikara ubai, watashi-o bujoku shita. (Author's translation)

4.action that is performed for subject's benefit: Кит әле, бир, үзем утыртам, - дип, мин курчакны Рәйсәдән тартып алдым. (А. Bikchentaeva) I told Raisa, “Get out, give it to me and I'll sit it by myself,” and took away the doll. 私はライサに「帰れ、人形は私が座 らせる」と言い、人形を奪い取った。Watashi-wa Raisa-ni 「kaere, ningyo-wa watashiga suwaraseru $\rfloor$ to ii, ningyo-o ubaitotta. (Author's translation)

As we can see in example 4), the construction with the verb -al (-aл) which means 'to take' or 'to receive' in Tatar language, as well as in Japanese, can express the action that is performed in the interests of the subject, but with a difference in its meaning. In Japanese, the benefactive construction with the auxiliary verb -morau has a meaning of gratitude to the beneficiary for the action performed in his interests, whereas in Tatar language the construction with a modificatory verb does not express such a meaning

\section{Discussion and conclusion}

Thus, we can see that constructions with verbs meaning 'to take' and 'to receive' exist in both Tatar and Japanese. It should be underlined, in Tatar linguistics these verbs belong to the group of modificatory verbs, whereas in Japanese they belong to the class of auxiliary verbs. As for the grammatical forms of usage of these verbs, it is identical in both languages: it consists of the verbal adverb and the verb which means 'to give' or 'to receive'. The forms with the verb 'to give' - ageru in Japanese and bir (бир) in Tatar - have a similar meaning. In both languages these forms can be classified as benefactive because they express the action performed in the interlocutor's interests. It should be mentioned that such forms are less likely to be used by the speaker when addressing the person that takes a higher position in the hierarchy in both Tatar and Japanese. As for the semantics of the form with the modificatory verb -al (-aл) that means 
'to take' / 'to receive' in Tatar and the auxiliary verb -morau meaning 'to receive' in Japanese, we concluded that these forms are, to some extent, semantically identical, but have a slight difference in its meaning.

ACKNOWLEDGEMENTS: The work is performed according to the Russian Government Program of Competitive Growth of Kazan Federal University.

\section{REFERENCES}

ALPATOV, V. M.; ARKADYEV, P. M.; PODLESSKAYA, V. I. Teoreticheskaya grammatika yaponskogo yazyka [Theoretic grammar of Japanese language]. Moscow, 2008. $336 \mathrm{p}$.

GLUSHKOVA, S. Y.; TKHOMPIRA, C.; SILAKOVA, S. A. Standard informative and expressive language tools in publicistic and journalistic texts of newspapers in the Chinese and Thai languages. Journal of Sociology and Social Anthropology, v. 10, n. 4, p. 214-218, 2019.

IBATULlinA, D. G.; ALIKBEROVA, A. R.; NASIROVA, S. A.; Modern linguistic trends in the japanese language. Journal of Research in Applied Linguistics, v. 10, p. 163-168, 2019.

ZAKIEV, M. Z. Tatarskaya grammatika v tryoh tomah [The Tatar grammar in 3 volumes]. Kazan: Tatarskoe knizhnoe izdatel'stvo, 1993. v. 2, 383 p.

\section{How to reference this article}

KHISAMOVA, V. N.; KHALIULlinA, A. A.; RASHITOVICH, R. M. A comparative analysis of the expressions of giving and receiving in the Tatar and Japanese languages. Rev. EntreLínguas, Araraquara, v. 7, n. esp. 3, e021040, Sep. 2021. e-ISSN: 2447-3529. DOI: https://doi.org/10.29051/el.v7iesp.3.15697

Submitted: $10 / 01 / 2021$

Required revisions: 20/03/2021

Approved: 23/06/2021

Published: 01/08/2021 